editor I disclaim. I beg, therefore, that you publish this letter in the next issue.

Bureau of American Ethnology,

J. W. Powell. WASHINGTON, D. C.

[In view of this letter and of others that have been received it is to be regretted that the note in question was admitted, especially without the signature of the writer. Leading newspapers that have supported President McKinley, such as the Philadelphia Ledger, the New York Evening Post and the Boston Transcript, have characterized his action in the appointment of a Fish Commissioner as weak and illegal, and it was supposed that this point of view would be shared by all men of science, however fully they might in other respects support the present administration.-ED. ScIENCE.]

\section{A CHARACTER REGULARLY ACQUIRED BUT NEVER INHERITED.}

ONE cause of the conflicting testimony concerning the inheritance of acquired characters is the difficulty of deciding whether a new or abnormal structure appeared in the individual after birth through a somatogenic change, or whether it was due to a prenatal or blastogenic variation. Whatever value we may attach to the present case, it is certainly interesting and avoids any difficulty of this kind.

The sternum of heavy perching birds belonging to the order Gallinacei, which includes the domestic fowl, the turkey and their wild ancestors, as well as the grouse, has the wellknown keel shape, and for some months after birth is semi-cartilaginous, and therefore soft and yielding. The keel is applied like a blunt knife edge to the hard perch. The transverse line of pressure caused by the weight of the body not supported by the legs soon produces a deformity which lasts for life. A cushionshaped enlargement may be formed, or the keel may be bent or twisted in a variety of ways. Some such deformity is inevitable from the mechanical conditions present. Moreover, this has been taking place not merely for a few generations, but during the whole course of the later evolution of these animals. At the end of each generation the individual variations thus acquired are completely effaced, and the young always begin life with the sternum normal.

The keel of the sternum in carinate birds has apparently arisen in correlation with the pectoral muscles concerned in flight, and if we assume that the variations which led to the keel were of a blastogenic character the inheritance of somatogenic changes which deform this structure could not at the same time have occurred. The keel has attained its present form, that of a thin vertical plate, in spite of those somatogenic changes in the life of the individual which tended to flatten and deform it.

No direct evidence that mutilations or deformities of a somatogenic nature are inherited has yet been obtained, and the theoretical improbability of such occurrences is very great. The fact that many animals preserve a characteristic form and symmetry from age to age, and even from one geological epoch to another, is evidence that somatogenic characters are not inherited and cannot be. It is well known that certain decapod Crustacea, such as some of the common crabs and the lobster, practice selfmutilation or autotomy. Here a special mechanism has been developed in the large cheliped by the action of which it is cut off in a certain way and at a definite place. When the large claw is seized by an enemy it is quickly amputated by the twitching of certain muscles stimulated by reflex nervous impulses, and a new limb in time grows out in place of the one cast off. The Lamarckian principle does not help us much in this case, nor in supposing that the germ cells in some mysterious way register every somatogenic change, even if this is not exactly reproduced in succeeding generations. Francis H. Herrick.

\section{THE THIRD INTERNATIONAL CONGRESS OF AP-} PLIED CHEMISTRY.

To the Editor of Science: The organization committee of the Third International Congress of Applied Chemistry, which is to be held in Vienna during the coming summer, has fixed the date of the meeting from the 28th of July to August 2, 1898. Some time during the month of February programs and announcements will 
be sent to all persons who have been enrolled as members of the Congress.

\section{H. W. WILEY, Chairman of American Committee. \\ U. S. Department of AGRiculture.}

\section{ELIZABETH THOMPSON SCIENCE FUND.}

ON February 14th last, at the twenty-third meeting of the Board of Trustees, the following new grants were made :

No. 79. $\$ 250$ to Professor Gustav Hüfner, Tübingen, Germany, for the investigation of hæmin and hæmatine. Application No. 743.

No. 80. $\$ 288$ to Professor Carlo Bonacini, Modena, Italy, for researches in color photography. Application No. 741.

No. 81. $\$ 250$ to Professor John Milne, Newport, I. W., England, to aid in a seismic survey of the world. Application No. 750.

Signed :

$$
\begin{aligned}
\text { Charles S. Minot, } \\
\text { Secretary. }
\end{aligned}
$$

\section{SCIENTIFIC LITERATURE.}

Text-book of Physical Chemistry. By Clarence

L. Speyers, Associate Professor of Chemistry, Rutgers College. New York, D. Van Nostrand Company. 1897. 8vo. Pp. vii +224 . Price, $\$ 2.25$.

"I have adopted the view that matter is a collection of energies in space, considering the relations of the energies to be the prime object of investigation. With Ostwald, I feel confident that the materialistic interpretation has passed its prime and has no promise in the future. Still, as this is a text-book, I give the prominent materialistic views of the present time."

These words, taken from the author's preface, make frank avowal of his scientific creed and indicate the point of view from which he proposes to discuss his subject.

Physical chemistry he defines as 'the science which has for its object the investigation of chemical changes by physical methods.' Concerning matter he says: "That which seems to cause a direct excitement of our senses we usually call matter." The italics are in the original. And again, "**** we can define the different forms of matter as collections of forms of energy in space. This definition is free from any speculation; it rests on experimental evidence alone."

Speaking of the seventy-five elements, or, as he terms them, 'collections which do not separate into other collections,' the author says : "We cannot, however, believe that all the seventy-five collections will ultimately be reduced to one or more single separate forms of energy, because in that case w.e should have nothing left to account for the collection of forms of energy in space. We need energy and a something to enable energy to collect in space before we get a material substance. This something which enables, and perhaps causes, the energy to collect in space we shall call matter. The dissimilarity in the innumerable substances known to us come from the differences in the natures and proportions of the forms of energy collected in space."

Quotation from the work has been made at such length, because, by so doing, the peculiar attitude of its author towards matter and energy could be most clearly depicted.

Undoubtedly in close sympathy with the 'ultra-dynamists,' he nevertheless does not seem wholly prepared to abandon entirely the idea of matter, matter, that 'something which enables, and perhaps causes, the energy to collect in space.'

The topics considered in this volume are : some general remarks on energy, gases, heat, physical changes, equilibrium, chemical kinetics, phases, electro-chemistry, ions.

The order in which these themes are presented appears, to a certain extent, haphazard, as if selected at random. For instance, in spite of the author's introductory lines to his final chapter: "In these last pages we consider some properties of the ions which do not seem to fit in elsewhere," it seems difficult to understand why these properties, alluded to here, were not discussed in connection with the rest of the subject which received full and deliberate treatment in the preceding chapter on electro-chemistry.

As to the manner of treatment accorded to various themes, this may be but the natural outcome of the policy pursued by the author, who in his preface states that he has not attempted to give an historical development of 